\title{
A comparative analysis of policies, strategies and programmes for information and communication technology integration in education in the Kingdom of Saudi Arabia and the republic of Ireland
}

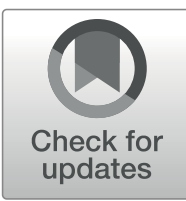

\author{
Jawaher Alghamdi ${ }^{1}$ (D) Charlotte Holland $^{2}$ (D)
}

Received: 10 December 2019 / Accepted: 16 March 2020 / Published online: 29 April 2020

(C) The Author(s) 2020

\begin{abstract}
This paper provides a comparative analysis of policies, strategies and programmes for Information and Communication Technology (ICT) integration in primary and postprimary education, that were active in the Kingdom of Saudi Arabia (KSA) and in the Republic of Ireland in 2016. The analysis showed that while KSA was a relative newcomer to the integration of ICT in education, it was responsive in seeking to enhance the quality of education and support transitions to the knowledge economy through a range of initiatives, including: reform of the curriculum, provision of teacher professional development in ICT integration, and supply of computer technologies and infrastructure. However, as in the Irish context, the framing of the ICT in education' policies, strategies and programmes needed to be strengthened through participatory partnerships with key stakeholders that endured throughout the life-cycle of ICT policy implementation in primary and post-primary settings. Furthermore, the review showed a need for governments in both jurisdictions to make better provision for financial and human resourcing to fully operationalize the teacher training and supports necessary for effective integration by teachers of ICT in primary and post-primary settings. Finally, the evaluation protocols within ICT in education' policies, strategies and programmes in both countries needed to be re-casted to make evidence of their enactment publicly available in a timely manner. Moreover, the resultant evaluation reports further needed to be detailed at a level that made visible the national progress on ICT integration in schools, and the corresponding impact on learners' ICT skills and broader competencies.
\end{abstract}

Keywords Saudi Arabia · Ireland · ICT in education · Policies

Jawaher Alghamdi

Jalghamdi@iau.edu.sa

Extended author information available on the last page of the article 


\section{Introduction}

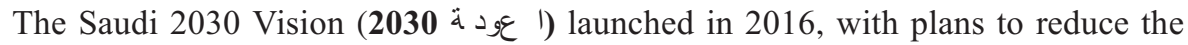
country's dependence on oil as the main income generator, and instead diversify into other economic sectors (Kingdom of Saudi Arabia 2016a). The Saudi 2030 Vision articulated a series of goals and accompanying programmes that aimed to bring about reforms across a broad range of systems, including education, to enable Saudi citizens to come to terms culturally with the new plans while also enabling them to become active participants in the necessary societal and economic transformations in a post-oil economy. Within the various plans contributing to the Saudi 2030 agenda, including the National Transformation Programme, 2016-2020 (Kingdom of Saudi Arabia 2016b), technology was frequently cited as a key agent in facilitating change and education was targeted as a means of enabling Saudi citizens to develop a broad range of new competencies, including digital skills, that aligned particularly with the new economic vision for the Kingdom of Saudi Arabia. It was within the context of these developments that the genesis of this idea to review ICT in education' policies, strategies and programmes that were active in the Kingdom of Saudi Arabia in 2016 was born, and this ultimately progressed to become a full-fledged comparative review of ICT in education' policies, strategies and programmes in the Kingdom of Saudi Arabia and the Republic of Ireland (ROI).

\section{ICT in education integration in the KSA and ROI}

This study engaged in a comparative analysis of ICT policy and programmes across the Kingdom of Saudi Arabia and the Republic of Ireland, and the reasons for choice of these jurisdictions were three-fold. Firstly, it was important to benchmark the ICT in education' policies, strategies and programmes in KSA with those from a western country with a track record in ICT policy implementation, and the ROI had actively engaged in ICT integration in education since the 1970s so was deemed suitable in this respect. Secondly, the Irish Higher Education Authority (2017) reported that the KSA was ranked as third largest country of origin (in a list of the top five countries outside the European Economic Area) for international students enrolled in Irish universities, and the majority of these students had government scholarships from the KSA. This suggested learning in, and from, the Irish education system was highly valued at governmental levels within the Kingdom of Saudi Arabia, and thus further contributed to this warrant to conduct the comparative analysis of the respective ICT in education' policies and practices of the KSA and ROI. Thirdly, the researchers of this study came from the Kingdom of Saudi Arabia and the Republic of Ireland, and both lectured and researched in ICT-enabled learning within higher education institutions, so they had a personal interest in the comparative analysis ICT policy implementation in education within and across both jurisdictions. To help set the context, an overview of the landscape of ICT integration in education-related policies and programmes within these national contexts is presented herein. 


\subsection{ICT in education integration in the Kingdom of Saudi Arabia}

The Kingdom of Saudi Arabia is a relative newcomer to prioritising the integration of technology in education, and this has had benefits in that there were many opportunities to learn from what has worked well (and to avoid the pitfalls) in terms of technology integration in other countries with a longer history of doing so. The Ministry of Education (MoE) in KSA began to make comprehensive reforms and created cohesive plans to redevelop the educational system and to improve student learning and educational outcomes by integrating ICTs in the curriculum and in pedagogic processes in the 1990s. The policies from the 5th Saudi National Development Plan (1990-1995) and the 6th Saudi National Development Plan (1996-2000), under the guidance of the Ministry of Planning (MoP, Kingdom of Saudi Arabia), resulted in ICT integration becoming more visible within the Saudi education system, with for example the introduction of computer science as an elective course in primary education and as a compulsory course in secondary education (MoP, Kingdom of Saudi Arabia 1990, 1996). The General Project for Curriculum Development (GPCD), a national project launched by the Ministry of Education in 1998, further aimed to develop education through ICT integration across a range of aspects, including: curricula, teachers' skills, teaching strategies and teaching and learning environment.

During the subsequent 7th, 8th and 9th Saudi National Development Plans (20002014), further actions to provide ICT skills training to teachers and learners, and to promote ICT integration in the classroom, were initiated by the MoP Kingdom of Saudi Arabia (2000) and the Ministry of Economy and Planning MoEP, Kingdom of Saudi Arabia $(2005,2010)$ respectively. The importance of integrating web-based technologies in teaching and learning contexts was foregrounded with the launch of the Watani project in 2000, the Saudi schools' net (Internet) project implemented by the Ministry of Education, which aimed to enhance ICT integration in education by initiating actions to: develop learners' ICT skills, enhance teachers' ICT skills, create ICT-enabled learning environments that were responsive to the needs of learners and teachers, improve educational processes to support effective ICT skills development, and prepare learners to engage in the knowledge economy (MoE, Kingdom of Saudi Arabia 2000). In 2007, the Ministry of Education implemented a country-wide project for general education known as the "King Abdullah bin Abdulaziz Project for General Education Development" which became known as the Tatweer project (2007-2023), which aimed to reform educational outcomes through a greater integration of technology in public school contexts. The Ministry of Education established the Tatweer Education Holding Company (TEHC) in 2008 to implement the Tatweer project. The Tatweer strategy had ten main goals including the goal 'to increase the use of ICT to improve the quality of education' (MoE, Kingdom of Saudi Arabia 2007), which was to be implemented through a range of development programmes focused on integration of ICT to: develop teachers' skills, develop curricula, enhance schools' activities and improve the school environment.

The 10th Saudi National Development Plan (2015-2019), launched by the Ministry of Economy and Planning in 2015, listed 24 objectives that were to be prioritised, which included the need to upskill teachers and learners in ICT (MoEP, Kingdom of Saudi Arabia 2015). The 10th National Development Plan thus supported actions that promoted ICT skills development and integration in education. Finally, the National 
Transformation Program (NTP) 2016-2020 was lunched by Kingdom of Saudi Arabia at the beginning of 2016 to respond to the Saudi Vision 2030 programme. The NTP programme had some general objectives underpinned by technological skills development and integration of technology within education systems, such as: 'improving the recruitment, training and development of teachers, improving the learning environment to stimulate creativity and innovation, and improving curricula and teaching methods' (Kingdom of Saudi Arabia 2016b).

\subsection{ICT in education integration in the Republic of Ireland}

According to McGarr (2009), the early days of computer usage in the 1970s within Irish schools was championed by mainly those teachers from the mathematics discipline who sought to enable learners to understand the key functions and operations of the computer and enhance programming skills. In the 1980s, computer usage in Irish schools moved towards becoming a stand-alone subject that focused on upskilling learners on common computer applications, such as work processing software (MarcusQuinn and McGarr 2013), and this focus on enhancing levels of ICT competence and literacy continued in the 1990s with the launch of the "Schools IT 2000" initiative in 1997. In the context of the Republic of Ireland, the Department of Education and Science/ Skills (DES) has been mainly responsible for ICT policy implementation across education. The Department of Education and Science launched its first ICT policy document in 1997, the aforementioned "Schools IT 2000", where the process of integrating ICT across the education system from 1997 to 2000 was outlined. The "Schools IT 2000" policy targeted actions for increasing technology-enabled classroom resources and infrastructures, as well as improving teachers' ICT skills and providing support for ICT integration in schools (DES, Republic of Ireland 1997). In order to implement the policy, the National Centre for Technology in Education (NCTE) was set up in 1998, and subsequently set out a framework for achieving the integration of ICT into education in Irish primary and post-primary settings. The NCTE was responsible for providing Irish schools with ICT support and training and further monitored integration of technology infrastructure in education through a series of national census exploring the availability of ICT infrastructure in schools (NCTE Census reports, 1998; 2000; 2002; 2005, as cited in the Inspectorate Report from the DES, 2008a). In 2001, the DES (2001) released a policy document entitled "Blueprint for the Future of ICTs (2001-2003)", with the main thrust of policy and associated programmes therein being to continue the main initiatives introduced under "Schools IT 2000" through to 2007. These included: expansion of ICT across schools, improved access to the Internet, further integration of ICT in teaching and learning, and enhancement of professional development for teachers (DES, Republic of Ireland 2001). In his critique of the formation of the "Schools IT 2000" policy, Johnston (2014, p.183) bemoaned the "lack of underpinning philosophy and clarity regarding educational purpose' which coupled with political and other external influences resulted in its implementation in Irish schools being negatively impacted by a 'techno-centric/ innovation-focused discourse' that continued in the roll-out of the "Blueprint for the Future of ICTs" programme.

In its 2007 National Development Plan, the Government of Ireland (GOI) further emphasised their commitment to promoting ICT-enabled learning with the allocation of just over a quarter of a billion euro to ICT integration in schools from 2007 to 2013 
(GOI 2007). In 2008, the "ICT in Schools: Inspectorate Evaluation Studies" report for the Department of Education and Science (DES, Republic of Ireland 2008a), further presented an analysis of the availability of ICT in schools with data collected from a range of sources including a national survey completed by principals and teachers, a questionnaire completed by learners, and school case studies undertaken during visits by inspectors. The main recommendations from the Inspectorate Report (DES, Republic of Ireland 2008a) were to seek ways to improve ICT capacity and to enhance training for teachers in using ICT in teaching and learning, and other recommendations highlighted that schools be shown how to use existing ICT infrastructure to further the integration of ICT in practice.

In 2008, the Irish Minister of Education and Science, Mary Hannifin, established a strategy group to further advise on priorities for investment of the National Development Plan monetary allocation for ICT integration in schools, which resulted in the publication of the "Investing Effectively in Information and Communications Technology in Schools, 2008-2013: The Report of Ministers' Strategy Group” report (DES, Republic of Ireland 2008b). This report highlighted seven key objectives and priority recommendations for ICT investment in education, including: continuing professional development, software and digital content for teaching and learning, ICT equipment, schools broadband and services, technical support and maintenance, implementation structures and supports, innovative practice and research. This report further provided an indication of desirable levels of ICT for schools, such as: a 5:1 pupil to computer ratio, computers being networked and broadband enabled, and for digital projectors and 'fixed' computer to be provided within each classroom. It further projected that 337 million euro of funding was needed in terms of ICT investment in education, and determined that the vast majority of this funding needed to be allocated on infrastructure, equipment and software (amounting to circa 281 million euro), and comparatively low levels of funding were to be allocated for CPD training and ICT in education advisory services (49 million euro), and for innovative practice and research ( 7 million euro). In 2009, the "Smart Schools = Smart Economy" (SSSE) report was published by the DES and this directed that a range of supports be made available to primary and post-primary schools for enhancing their integration of ICT, relating to: 'Classroom and student infrastructure, technical support and the virtual learning environment (VLE), Teacher Professional Development, ICT planning and multi-annual budgeting, Digital content growth and Enhancement broadband for schools' (DES, Republic of Ireland 2009, p. 6). However, while improvements in broadband infrastructure and access to technology had undoubtingly enhanced the presence of ICT in schools from 2000 onwards, and the policy recommendations from the DES in the 2007-2009 period intended to further this ICT integration in education, the impact of economic recession and the necessary economic austerity measures implemented in Ireland from late 2008 onwards meant that key supports such as the national ICT advisor network for schools were removed, and thus progression towards the meaningful integration of ICT in education was significantly curtailed (Conway and Brennan Freeman 2009, 2015).

The advancement of ICT integration in education in effect re-started in 2014, with signs of recovery in sight for the Irish economy, and was enabled through the articulation of a new curriculum framework within post-primary education, namely, the Framework for Junior Cycle (DES, Republic of Ireland 2015a), as well as the ICT Skills Action Plan 2014-2018 (Department of Education and Skills, DES \& 
Department of Jobs, Enterprise \& Innovation, DJEI, Republic of Ireland 2014), the Action Plan for Education 2016-2019 (DES 2016), and the Digital Strategy for Schools 2015-2020 (DES, Republic of Ireland 2015b). The "Framework for Junior Cycle 2015" developed by the DES, set out to improve teaching, learning and assessment practices to support the delivery of a quality, inclusive and relevant education of students in the first 3 years of their post-primary education. Within this document, the role of technology in strengthening the diversity of teaching approaches and assessment, whilst also enabling digital skills development among learners, was highlighted. The "ICT Skills Action Plan 2014-2018", a collaboration that was led by the Department of Education and Skills (DES) and Department of Jobs, Enterprise and Innovation and Industry (DJEI), and implemented in partnership with state agencies and industry stakeholders, sought to improve ICT skills of learners of all ages to support long-term economic development in Ireland. The ICT Skills Action Plan had 22 actions including: improvement of school infrastructure, teacher professional development, and re-development of curriculum. The "Action Plan for Education 20162019", developed by Department of Education and Skills, provided a strategic overview of the education and training reform programme. This action plan had five main objectives:

1)improve the learning experience and the success of learners, 2) improve the progress of learners at risk of educational disadvantage or learners with special educational needs, 3) help those delivering education services to continuously improve, 4) build stronger bridges between education and the wider community, and, 5) improve national planning and support services. (DES, Republic of Ireland 2016, p. 2).

The “Digital Strategy for Schools 2015-2020" was a five-year digital strategy aimed at enhancing the use of ICT in teaching, learning and assessment within primary and postprimary education contexts. This strategy had four key themes: 'Teaching, learning and assessment using ICT, Teacher professional learning, Leadership, research and policy, and ICT Infrastructure' (Department of Education and Science DES, Republic of Ireland 2015a, p.6), which were underpinned by financial resourcing and training supports as drivers towards effecting positive changes in education infrastructure, and practices.

\section{Methodology}

The overarching research question for this study was to compare and contrast policies, strategies and/ or programmes (active in 2016) aimed at enhancing the integration of ICT in primary and post-primary education settings in the Kingdom of Saudi Arabia and the Republic of Ireland, with a view to identifying similarities and/ or differences in the framing of these and discussing implications of same. The sub-research questions were framed as follows: 
- What rationales underpin the integration of ICT in primary/ post-primary education policies, strategies and/ or programmes at a national level in Saudi Arabia and Ireland?

- What operational components have been integrated within these national strategies and programmes in both jurisdictions?

- What structures have been included to enhance leadership and accountability with respect to these policies, strategies and/ or programmes?

- How do the national policies, strategies and/ or programmes for the integration of ICT in primary/ post-primary education settings compare across both jurisdictions?

The methodology of this study utilized Kozma's (2008) Framework for Comparative Analysis of ICT Policy to critically review policies, strategies and/ or programmes (active in 2016) that sought to enhance ICT integration in education in two settings, Kingdom of Saudi Arabia and Republic of Ireland. In his framework for comparative analysis, Kozma (2008) suggested four policy rationales that can facilitate an analysis of the vision or purpose of ICT policy, and a further five operational elements that can be used for analysis of ICT programme/s. The four high-level policy rationales were to be viewed as visions embedded within the strategic policy, such as: supporting economic growth, promoting social development, advancing education reform and supporting education management. Kozma (2008) acknowledged that some policies can combine two or more of these rationales, and thus a fifth element 'Multiple Rationales' component can be added to capture this. In terms of the operational elements that could be compared and contrasted across ICT programmes in

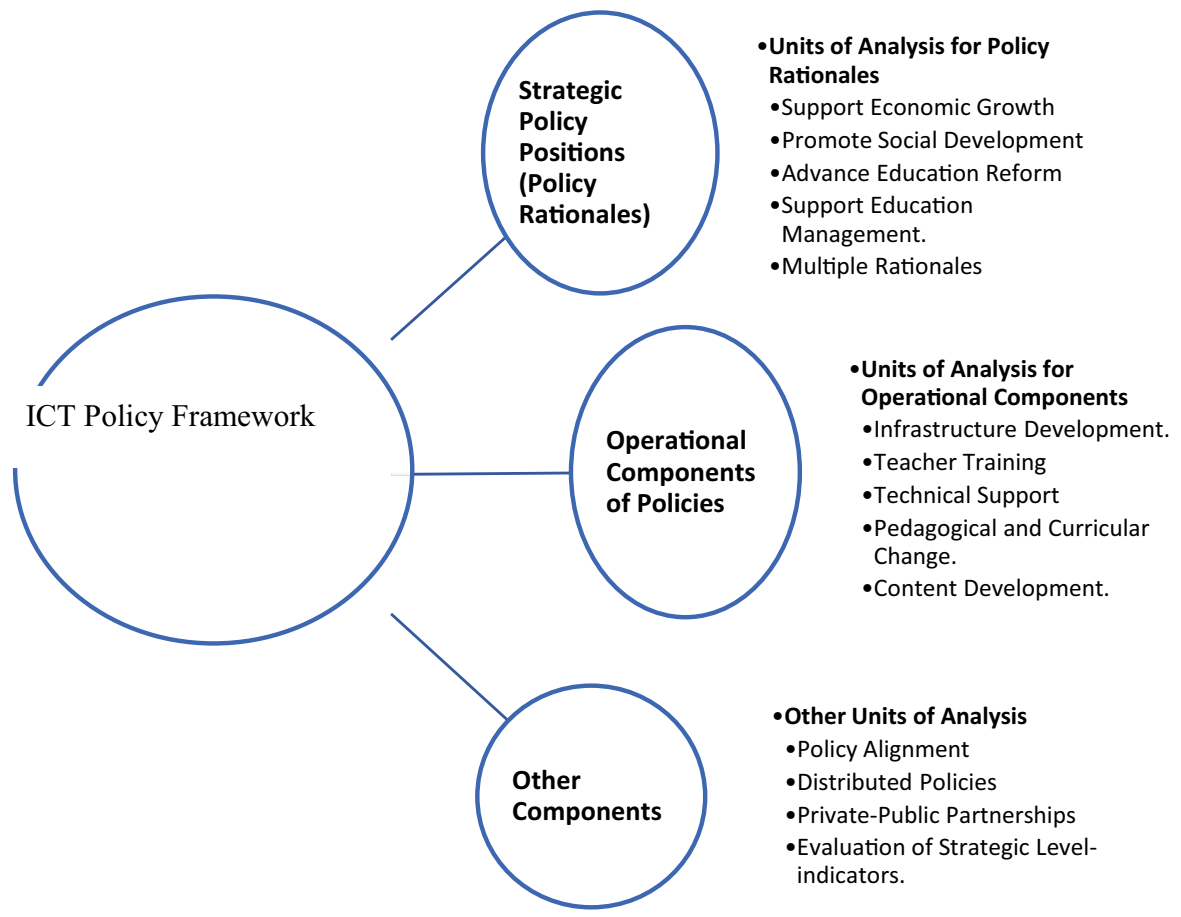

Fig. 1 Kozma's Framework for Comparative Analysis of ICT in Education Policy 
education, Kozma (2008) included: Infrastructure Development, Teacher Training, Technical Support, Pedagogical and Curricular Change, and Content Development. Kozma (2008) further recommended some other components that can be used in the analysis of ICT action plan and/or programmes and these include: Policy Alignment, Distributed Policies, Private-Public Partnerships and Evaluation of Strategic Level. Kozma's (2008) framework thus provided the units of comparative analysis (as illustrated in Fig. 1) for this critical review.

The analysis of ICT integration within and across the national policies and related programmes in the Kingdom of Saudi Arabia and the Republic of Ireland was undertaken through the application of Kozma's (2008) framework for comparative analysis of ICT policy. The overall process of analysing the active policies and programmes across both jurisdictions was thus framed by examination of Kozma's (ibid) two main categories of 'Policy Rationales' and 'Operational Components', with further exploration of what Kozma categorised as 'Other' - namely, alignment of policies and programmes, partnership model/s and evaluation planning. The aforementioned units of analyses (articulated within each category of Kozma's 2008 frame for comparative analysis of ICT policy as illustrated in Table 1) formed the structure for the review process, with the ICT policies and programmes in each jurisdiction coded and categorised accordingly, and further guided the focus of the resultant analysis of policies. In this regard, the ICT policies and programmes were reviewed for evidence of: underpinning rationale/s for the ICT policy including whether the policy/ plan primarily sought to support economic growth, promote social development, advance the reform of education and/ or support education management. Furthermore, there was a review of the operational components of policies including whether there was reference to support for and promotion of ICT infrastructure development, teacher training in ICT, technical support, pedagogical and curricular change and content development vis-à-vis ICT integration in education. Finally, the policies and related programmes were reviewed to see whether there existed alignment of ICT policies and programmes within and across the target countries, or whether there were distributed policies, whether public-private partnerships were established to support the integration of ICT, and whether there was explicit integration of evaluation processes for the strategic level indicators. Therefore, Kozma's (2008) framework for comparative

Table 1 Active policies and programmes referring to ICT in Education in the Kingdom of Saudi Arabia and Republic of Ireland in 2016

Active Policies and Programmes referring to ICT in Active Policies and Programmes referring to ICT in Education in the Kingdom of Saudi Arabia in 2016 Education active in the Republic of Ireland in 2016

-General Project for Curriculum Development (1998-current).

-The National Strategy for the Development of Education (NSDE), King Abdullah Project for General Education Development (known widely as the Tatweer project), (2007-2023).

-10th National Development Plan (2015-2019).

-National Transformation Program, NTP, (2016-2020) to achieve the Saudi Vision 2030.
-ICT Skills Action Plan (2014-2018) - Irish Department of Education and Skills, and the Irish Department of Jobs, Enterprise and Innovation.

-Action Plan for Education (2016-2019) - Irish Department of Education and Skills.

-Digital Strategy for Schools (2015-2020) - Irish Department of Education and Skills.

-Framework for Junior Cycle (2015) - Irish Department of Education and Skills. 
analysis of ICT Policy allowed for the findings for both jurisdictions to be drawn together for comparison and critique.

The national policies, strategies and programmes relating to ICT in education were sourced from a search of governmental websites in the Kingdom of Saudi Arabia and the Republic of Ireland, and further searches were conducted within websites of international organisations/ bodies (including: World Bank, UNESCO, EU) and within academic databases (including: Wiley, Springer, Emerald) to identify reports on the implementation of ICT policies in the primary and post-primary education systems (during the timeframe of review in 2016). The key search terms used included: ICT in education, acts, policies, strategies, plans, programmes, Ireland, Saudi Arabia, evaluation of ICT in education. At a national level, this resulted in the identification of four relevant documents for each jurisdiction (active at the time of study in 2016) as listed in Table 1 relating to the framing and implementation of ICT in education policies, strategies and programmes in the aforementioned countries.

In the Saudi context, there was very limited information available publicly or in academic literature on the review of the implementation of ICT in education' policies, strategies or practices, with the "Report of the General Project for Curriculum Development" (2012) for example being the most recent, publicly available evaluation report at the time of this study, of the General Project for Curriculum Development (1998). Similarly, within the Irish context, there was very little information available publicly or in academic literature of the ICT in education' policies, strategies or programmes active in 2016, which perhaps was less surprising as many of these were still in the early stages of being implemented at the time of the review.

\section{Review of strategic policies, strategies and Programmes within the Kingdom of Saudi Arabia and the Republic of Ireland}

The discourse presents a review of strategic policies, operational components, and other factors including evaluation strategies, and policy/ programme alignment within and across governmental departments within each national context.

\subsection{Review of strategic policies: Programme rationale/s}

As identified by Kozma (2008), the rationale for many strategic policies pitched to drive agendas for ICT integration in education tend to fall within one or a combination of the following - 1) to support economic growth, 2) social development, 3) advance education reform and/or 4) support education management. This section compares and contrasts the underpinning rationale/s for strategic policies in Ireland and Saudi Arabia that were active in 2016.

\subsubsection{Support economic growth}

In the Saudi context, all of the aforementioned policies and plans made some reference to the need to integrate technology in education as a means to prepare learners for the labour force and thus contribute to economic growth. In terms of the General Project for Curriculum Development (MoE, Kingdom of Saudi Arabia 1998), this strategy 
(which had no specific end date) aimed to integrate ICT in ways that enabled promotion of the type of learning and performance that meets the needs and requirements of the labour market, whilst supporting economic growth. Similarly, the focus of the Tatweer project initiated by the $\mathrm{MoE}$ in 2007 was to enhance '... the quality of education to ensure that all students are equipped with the necessary skills to develop their country and achieve sustainable knowledge economy' (p. 26). Furthermore, the focus of the 10th Saudi National Development Plan (2015-2019) was to promote the knowledgebased economy by enhancing '... the main determinants of productivity and economic growth through focusing on information technology and education to achieve distinct economy' (MoEP, Kingdom of Saudi Arabia 2015, p. 38). In addition, the Saudi National Transformation Programme 2020 aimed to prepare young Saudis with general and basic skills to enable them to live and work in a global economy (Kingdom of Saudi Arabia 2016b).

Likewise, in the Irish context, within the aforementioned policies and plans relating to ICT integration in education, reference was made to the need to prepare learners for the labour force and contribute to economic growth. The ICT Skills Action Plan 20142018 was very much focused on promoting economic growth within the ICT sector through among other things the reform of education. This plan was developed to 'increase the supply of highly skilled ICT professionals from abroad to complement the increase in the domestic supply of high level ICT graduates from the education system' (DES \& DJEI, Republic of Ireland 2014, p. 5). The Action Plan for Education (2016-2019) referred to the need to prepare learners for a digitally connected world, and to enhance their capacity to meet national and regional skills needs, such as those outlined within the aforementioned ICT Skills 2014-2018 action plan - objective 4.3 (action point number 91) made explicit the connection between the Action Plan for Education, ICT and the economy - 'Develop innovative responses to skills gaps across key priorities areas of the economy including ICT, languages, biopharma' (DES, Republic of Ireland 2016, p.45). Moreover, the Digital Strategy for Schools, 20152020, also was developed to 'take account of the recent economic challenges and looking to the future and the anticipation of economic growth' (DES, Republic of Ireland 2015b, p.10). Similarly, within the rationale for changes to the Junior Certificate curriculum as outlined within the Framework for Junior Cycle 2015, the need to prepare learners for knowledge economy and to prepare them for labour force was called out (DES, Republic of Ireland 2015a).

\subsubsection{Promote social development}

In the Saudi context, three of the aforementioned policies and plans made some reference to the need to integrate technology in education to promote social development. A key aim of the General Project for Curriculum Development (MoE, Kingdom of Saudi Arabia 1998) was to help prepare Saudi learners to cope with the rapid changes in Saudi society in terms of culture, daily life and expansion of cities/ towns (population movements from rural to urban settings). It was hoped that curricular reforms such as including ICT to support quality learning experiences would ultimately support smoother cultural and societal transitions towards becoming more digitally connected within the Saudi context. The Tatweer project (MoE, Kingdom of Saudi Arabia 2007) recognised the importance of ICT in enhancing and supporting social 
development among learners. The 10th Saudi National Development Plan (MoEP 2015) outlined the importance of CT in increasing parental participation in learning and also in developing learners' personal and inter-personal dispositions and skills such as: morals, values, communication, teamwork, leadership. The Saudi National Transformation Program (Kingdom of Saudi Arabia 2016b) made some reference to the promotion of social development, including increasing number of women and people with disabilities in the workplace, and the role of technology in healthcare matters, however, there was no explicit reference to the role of ICT in education in enabling these.

In the Irish context, three of the policies and plans made some reference to the need to integrate technology in education to promote social development of learners. The Digital Strategy for Schools 2015-2020 supported the use of ICT as a tool to transform teaching, learning and assessment, in ways that enabled learners to develop twenty-first century skills such as collaboration with peers, as well as higher order thinking skills, self-directed skill-sets, and to encourage them to take ownership of own learning (DES, Republic of Ireland 2015b). Furthermore, the DES pointed to a key objective of the Action Plan for Education 2016-2019, being to create a "step-change" (DES, Republic of Ireland 2016, p.16) that would re-orient the use of ICT in teaching, learning and assessment at all levels so that learners were appropriately equipped to live in an increasingly digitally connected world. The significance of ICT integration from a social perspective was further highlighted within the learning statements of the Framework for Junior Cycle (DES, Republic of Ireland 2015a). For example, two of these learning statements (19 and 24 as shown below) highlighted that the integration of technology in education was highly valued, in terms of its role in supporting the development of life-skills (such as communication, lifelong learning, collaboration, creative thinking, translation of knowledge into practice).

19. values the role and contribution of science and technology to society, and their personal, social and global importance24. Uses technology and digital media tools to learn, communicate, work and think collaboratively and creatively in a responsible and ethical manner (DES, Republic of Ireland 2015a, p. 57-58).

The ICT Skills Action Plan (2014-2018) did not explicitly refer to the social development with its rationale, but it could be argued that it indirectly supports ICT integration for social development by its reference to the need to implement the Digital Strategy for Schools (2015-2020) and the junior cycle reform programme i.e. the Framework for Junior Cycle (2015).

\subsubsection{Advance education reform}

In the Saudi context, three of the aforementioned policies and plans made some reference to the need to integrate technology in education to advance education reforms. The General Project for Curriculum Development (MoE, Kingdom of Saudi Arabia 1998) spearheaded a major reform of the curriculum with the primary aim to prepare learners for the knowledge economy through enhancement of skill-sets such as thinking skills, problem-solving skills, self-learning skills, collaborative learning, and communication, while recognising that ICT played an important part in supporting the development of these skills-sets. In terms of the Tatweer project (MoE, Kingdom of 
Saudi Arabia 2007), it was developed to reform the education system through supply and support of the much-needed technology infrastructure in public settings and through provision of teacher ICT training. Likewise, the 10th National Development Plan, 2015-2019 contained a programme for education that sought to enhance economic growth through reform of education systems, specifically "improve the learning environment to stimulate creativity and innovation and provide citizens with knowledge and skills to meet the future needs of the labor market'. (MoEP, Kingdom of Saudi Arabia 2015, p.60). The National Transformation Program, NTP, (2016-2020) in essence was a reform programme seeking to contribute to transformation in economy and society outlined within Saudi 2030 Vision (Kingdom of Saudi Arabia 2016b). However, the NTP program didn't explicitly call out the use of ICT in the reform of education but did mention the digitization of education as an action within the development of the digital economy.

In the Irish context, all of the aforementioned Irish ICT policies and/ or plans made some reference to integrating technology in education to advance education reform, with ICT being out forward mainly as a vehicle for new approaches to teaching, learning or assessment. The Digital Strategy for Schools 2015-2020 in itself could be considered an education reform programme developed to support the integration of ICTs to enhance the progression of education reform and support the development of active and informed citizenry. It thus spoke to advancing educational reform through its promotion of digital technologies to 'enhance teaching, learning and assessment so that Ireland's young people become engaged thinkers, active learners, knowledge constructors and global citizens to participate fully in society and the economy' (DES, Republic of Ireland 2015b, p. 5). Furthermore, within the Action Plan for Education 2016-2019, a whole-systems reform approach was envisaged underpinned by the key principles of access, excellence, transparency and innovation, with technology integration a key agent in its ambitious aim 'to deliver high quality education and training experiences that equip learners with the knowledge and skills that they need to achieve their potential and to participate fully in society and the economy' (DES, Republic of Ireland 2016, p. 6). Moreover, the ICT Skills Action Plan (2015-2020) noted the need to support ICT skills development allied to curricular reforms, with explicit reference to Junior Cycle reform programmes (DES \& DJEI, Republic of Ireland 2015). Finally, the Framework for Junior Cycle (DES, Republic of Ireland 2015a) was positioned as a reform agenda for education for those learners aged 12-15 (lower post-primary level), and it made some reference to the use of ICT, mainly digital media, as a medium through which particular learning outcomes can be realised within subject areas, and to the need for learners to learn the skills of coding.

\subsubsection{Support education management}

In the Saudi context, there was very limited explicit reference within the policies and plans (active in 2016) to the need to integrate technology in education to support education management. In fact, the Tatweer project brief (MoE, Kingdom of Saudi Arabia 2007) was the only one of those reviewed to specify a technology-enabled system that could manage educational process i.e. the "Noor e-system" which was to include facilities to track and report on students' attendance and performance, and teacher's attendance, as well as timetabling facilities to structure organisation of classes. 
Similarly, in the Irish context, there was very limited reference within the policies and plans that were active in 2016 to the need to integrate technology in education to support education management. The Digital Strategy for Schools (2015-2020) did mention the potential of technology to provide feedback on learner performance to teachers and parents. In this regard, the suggestion was that teachers could review learner performance through data gleaned from learner interactions within 'simulations, digital games, virtual worlds, virtual labs and ePortfolios' (DES, Republic of Ireland 2015b, p.24). The Framework for Junior Cycle (DES, Republic of Ireland 2015a, p.39) further made a reference to 'the potential of ICT to support' teachers from different schools to collaborate in subject learning and assessment review meetings.

\subsection{Review of operational components of policies/Programmes}

The evidence of consideration of operational components of ICT integration in education as outlined by Kozma (2008) included the presence of one the following components within policies, strategies and programmes: 1) Infrastructure development, 2) Teacher Training, 3)Technical Support, 4) Pedagogical and Curricular Change, and 5) Content Development. These operational components were thus reviewed in terms of their visibility in the descriptions of how the strategic vision was to be realized within the targeted policies, strategies and programmes.

\subsubsection{Infrastructure development}

In the Saudi context, there was considerable articulation of infrastructure development within the Tatweer project plan (MoE, Kingdom of Saudi Arabia 2007) which sought to invest in and expand the use of appropriate technologies across Saudi schools. The Tatweer plan (2007-2023) stated as its aim that it set-out to ensure that all schools have good ICT infrastructure and further detailed that some of these supports would include supplying computers and other ICT equipment along with high speed Internet connectivity to schools in the Kingdom of Saudi Arabia. Furthermore, the 10th National Development plan (2015-2019) also re-iterated its plan to provide schools with the necessary ICT infrastructure (MoEP, Kingdom of Saudi Arabia 2015).

In the Irish context, there was explicit reference within the Digital Strategy for Schools (2015-2020) and the Action Plan for Education (2016-2019), to the need for supports in ICT infrastructure development. Within the Digital Strategy for Schools (2015-2020), the Irish Department of Education and Skills reported that investment in national ICT infrastructure (specifically improved connectivity through broadband services, and grants for schools to purchase ICT equipment) would be extended to include all post-primary schools and a number of special schools with post-primary students, as well as the primary school settings (Department of Education and Science, Republic of Ireland, 2015a). The DES further pointed to trends regarding the role of cloud computing in education, and learners being encouraged to bring their own devices (BYOD) to schools. With respect to the latter, the DES noted the potential of engaging in BYOD practices in terms of progressing ICT integration in schools but pointed to the need for the provision of advice and support for schools with regard to potential issues in doing so, and in enabling schools to make informed decisions at local levels regarding infrastructural requirements. The Action Plan for Education 
(2016-2019) made explicit reference to the implementation of the Digital Strategy for Schools (including investment in infrastructure such as high-speed broadband for primary schools) within its pathway (DES, Republic of Ireland 2016).

\subsubsection{Teacher training}

In the Saudi context, there was recognition of the need for teacher training to develop ICT competency within the Tatweer project brief (2007-2023). The Tatweer project plan included an overview of an ICT competency framework, with a focus on building teachers' skills in infusing ICT in their teaching and learning practices (MoE 2007). Furthermore, the role of technology in enabling communities of practice was recognised within the Tatweer project, with opportunities for teachers to connect and exchange best practice in using technology for learning and teaching purposes. Moreover, the Tatweer plan referred to the forging of partnership with educational colleges that would enable the development of teacher training programmes focused on the usage of ICTs across the curriculum. The National Transformation Program (20162020) also mentioned the need for teacher professional development and the inclusion of ICT within 'the comprehensive framework for continuing professional development for teachers and educational leaders' (Kingdom of Saudi Arabia 2016b, p. 100).

In the Irish context, there was recognition of the need for teacher training to develop ICT competency within the Digital Strategy for Schools 2015-2020, in which the DES (2015b) called out the need for advice and guidance to be provided for teachers and schools with respect to the effective, critical, and ethical integration of ICT, along with examples of authentic and good practices in teaching learning and assessment using ICT. Within the Digital Strategy for Schools 2015-2020, there was further confirmation of the need for adaptation and localisation of the UNESCO ICT Competency Framework (2018) for teachers working in Irish school contexts, in order to enable schools to "have greater clarity around the concept of ICT integration" (DES, Republic of Ireland 2015b, p. 6).

\subsubsection{Technical support}

There was just one reference to the need for technical support within the Saudi policies or programmes that were active in 2016, and this was within the National Strategy for the Development of Education (NSDE), King Abdullah Project for General Education Development - Tatweer project (MoE, Kingdom of Saudi Arabia 2007). The other programmes and strategies did not make explicit the need for technical support for teachers or schools within their plans.

In the Irish context, the DES didn't explicit refer to technical support for ICT integration within its Framework for Junior Cycle (Department of Education and Science, Republic of Ireland, 2015a), but did commit to providing exemplar materials and complementary online support through its online website for teachers of junior cycle, and social media channels. Furthermore, in the Action Plan for Education (20162019), there was reference to providing grants, advice and support materials for ICT equipment, and investing in the professional development of teachers in this regard (DES, Republic of Ireland 2016). There was also recognition in the Digital Strategy for Schools 2015-2020 that schools faced challenges in acquiring appropriate technical 
support, and commitment to engage in a review of 'technical support options with a view to providing guidance on the best technical support solution for schools' (DES, Republic of Ireland 2015b, p. 7). During the formulation of this Digital Strategy for Schools, the DES noted that 'schools identified the challenge of attaining reliable and timely technical support as a major issue. In addition, schools had very diverse needs in terms of technical support, which would require technical providers to have a high level of technical knowledge and expertise that is relevant to different school settings or contexts' (DES, Republic of Ireland 2015b, p.43). The Professional Development Services for Teachers (PDST), which incorporated the former National Centre for Technology in Education in 2012, was appointed to provide technical and pedagogic support for this strategy for integrating ICT in education systems and practices. In 2017, the DES further released a detailed Digital Learning Framework (DLF) (Butler et al., 2018), a key action from the Digital Strategy for Schools 2015-2020, as a guide for schools to promote the integration of ICTs in teaching, learning, assessment, and within educational management of school systems and processes, and to self-evaluate their performance in doing this. In their evaluation of the Digital Learning Framework implemented in school settings in 2017-2018 undertaken, Cosgrove et al. (2019) from the Educational Research Centre (ERC) reported that there was progress with respect to integration of technology in schools but this varied considerably across primary and post-primary settings. Cosgrove et al. (2019) further pointed to the unreliability of wi-fi and slow computers in some schools, noting that technical support was highlighted as a significant obstacle to integrating digital learning in practice for teachers and advisors in many school settings.

\subsubsection{Pedagogical and curricular change}

In the Saudi context, as already mentioned, the Tatweer project plan (MoE, Kingdom of Saudi Arabia 2007) pointed to improving the quality of learning by connecting teachers with peers to exchange best practice on integrating ICT in their relevant discipline/s. However, the Tatweer project briefing lacked detail on how ICT would be used to support assessment.

In the Irish context, as already mentioned the Digital Strategy for Schools (20152020) committed to providing guidance and examples of good practice on the integration of ICT in teaching, learning and assessment, which would contribute to enhancement of pedagogical and curricular practices. Furthermore, within this strategy, the DES, Republic of Ireland (2015b) committed to the articulation of the necessary digital skills and related learning outcomes in the new curricula throughout the lifetime of the digital strategy. A possible criticism of the strategy was that there was not enough detailing within the strategy on what should be included in terms of learners' digital competencies and how technology should or could support assessment, pedagogical and/ or curricular change - its focus instead appeared to be mainly on identifying teacher competencies vis-à-vis technology integration. Within the Digital Strategy for Schools (2015-2020), there were calls for the development of learners' levels of digital literacy by including coding and programming in the Irish primary and post-primary curriculum, whereby learners would learn core problem-solving and life-skills such as computational thinking, logic, critical thinking and strategic thinking. In the Action Plan for Education (2016-2019), there was reference to the provision of continuing 
professional development for teachers in the use of ICT in teaching, learning and assessment.

\subsubsection{Content development}

In the Saudi context, there was recognition within the 2010 report on the progress of General Project for Curriculum Development (MoE, Kingdom of Saudi Arabia 1998) of the need to integrate ICT into the curriculum and provide learners with digital content and other resources related to the curriculum such as educational video, multimedia, e-book and website/s. Moreover, the National Strategy for the Development of Education (NSDE), King Abdullah Project for General Education Development - Tatweer project (MoE, Kingdom of Saudi Arabia 2007) briefing documentation committed to upgrading the educational portal to provide educational content that facilitated sharing of experiences by teachers and learners. Furthermore, it committed to engagement in Interactive Digital Content curriculum development, thus enabling the transformation of all curriculum into online and off-line 'interactive' experiences, supported by multimedia content on smart phones, tablets and iPads and a central education portal. Furthermore, the MoE committed to providing high quality digital learning experiences for all students through the establishment of an e-school, built by a team of specialists to lead and manage it (MoE 2007). Within the Saudi National Transformation Program (2016-2020) there were further commitments made to improving curriculum, teaching and assessment methods through 'shifting to digital education to support teacher and student progress' (Kingdom of Saudi Arabia 2016b, p. 100).

In the Irish context, there was recognition of the need for content development within the eight key skills within the Framework for Junior Cycle (DES, Republic of Ireland 2015a), which also directly referenced digital competencies that enhance the learning and life-skills of learners. In this regard, the DES noted specialist short courses in coding and digital media literacy were to be offered within the revised Junior Cycle Framework. Teachers were also to be offered continuing professional development to transition to the new framework, and additional resources and online support were to be made available to support teachers in enhancing the learning environment through use of ICT. In the Action Plan for Education (2016-2019), there was reference to actions for 'increased technology-enhanced and blended learning opportunities' (MoE, Kingdom of Saudi Arabia 2016, p.16). Furthermore, the Digital Strategy for Schools (20152020) included a commitment by the DES, Republic of Ireland (2015b) to support all learners with high-quality digital content, whilst also supporting national educational portals, such as 'Scoilnet' and the 'Arts in Education' portal. The DES further indicated within this plan that it would support alternative means of assisting schools to access digital content, such as the purchase of digital resources relevant to the curriculum.

\subsection{Review of other components impacting policy}

The analysis process concluded by review of policy/ programme alignment and embedded evaluation strategies where explicated, across governmental departments within the Saudi and Irish contexts.

In the context of the Kingdom of Saudi Arabia, the National Strategy for the Development of Education (NSDE), King Abdullah Project for General Education 
Development - Tatweer project (MoE, Kingdom of Saudi Arabia 2007) aligned with other national plans including the 9th and 10th Saudi National Development Plans (MoEP, Kingdom of Saudi of Arabia 2010, 2015), and the Saudi National Transformation Programme 2016-2020 (Kingdom of Saudi Arabia 2016b), all of which involved close coordination and collaboration across a range of governmental departments, including the Ministries of Education, Communications, and Information Technology. There was no explicit reference to the role of distributed leadership in any of the reviewed strategies and programmes. In relation to reviewing performance of these plans, the Saudi Ministry of Education (MoE, Kingdom of Saudi Arabia 2007) acknowledged the importance of measuring the outcomes from the implementation of their action plans and projects progressing integration of ICT in education. Therefore, the final phase of each action/ project had an evaluation section to annually measure the strategies' outcomes. However, evaluation reports for other Saudi policies, strategies and programmes were not accessible for review beyond the relevant KSA Ministry, so were not available for review at the time of this study.

In the Irish context, the Digital Strategy for Schools (2015-2020) aligned with, and provided support for, the ICT Skills Action Plan (2014-2018), which aimed to 'ensure young people have the necessary knowledge and skills to contribute to and participate in modern society' (DES \& DJEI, Republic of Ireland 2014, p.10). The rollout of broadband to primary and post-primary schools programme was jointly funded by the Department of Communications, Energy and Natural Resources (DCENR) and the Department of Education and Skills, showing alignment and collaboration across two different governmental departments in the implementation of the policy to improve Internet access to all primary and post primary schools. The Action Plan for Education (2016-2019), was closely aligned to a number of ICT integration strategies and included cooperation across a number of other Departments, including the Department of Education and Skills, and their agencies. For example, it aligned with the Digital Strategy for Schools (2015-2020) which aimed to invest in infrastructure such as highspeed broadband for primary schools. Within the Digital Strategy for Schools (20152020), there was a separate theme titled: Leadership, Research and Policy, under which the need for distributed leadership in order to truly integrate ICT across the education system was highlighted by the DES, Republic of Ireland (2015b). Therefore, within the Digital Strategy for Schools, the important role of the DES and associated agencies in providing "strong leadership in supporting schools to effectively integrate ICT into teaching, learning and assessment" (DES 2015b, p.7) was recognised, while it was also recognised that also school management and key stakeholders needed to provide leadership and ownership in this process, so that "we achieve ICT integration and equip learners with the digital competencies that we value" (DES, Republic of Ireland 2015 b, p.7). In addition, the DES (2015b) recognised the need for regular evaluations to monitor the meaningful integration of ICTs in education, and in assessment of progress in this regard. The DES (2015b) further recognised the importance of researching and sharing of good practices in integration of ICT in Education within the wider teaching community to enhance the overall educational experiences of young people across the system. Finally, the DES, Republic of Ireland (2015b) cautioned of the dangers of mis-use of ICTs in education and committed to providing guidance and supports to ensure the effective, safe and ethical use of ICTs is embedded within school policies and practices. 


\section{Comparative review of ICT in education policies, strategies and Programmes across KSA and ROI}

In terms of both the Saudi and Irish contexts, the review of rationales underpinning policies, strategies and programmes focusing on ICT integration in primary and postprimary education, perhaps unsurprisingly found evidence of a primary focus on using ICT integration to progress the type of educational reform that would enhance economic growth across both countries, with social development more visible within the Irish policy framework. This speaks to national agendas in both jurisdictions that sought to mobilise ICT integration in education to prepare a work-force for the knowledge economy. Furthermore, the importance of partnership was evident within the formation and implementation of policies, strategies and programmes, evidenced by partnerships across governmental departments and consultation with stakeholders across education, industry and civil society sectors within each jurisdiction.

The Saudi government mandated through their policies that Saudi teachers adopt ICT in their practice, highlighting the importance of ICT integration in education within the General Project for Curriculum Development (MoE, Kingdom of Saudi Arabia 1998), committing to dedicated support for ICT integration through the Tatweer project (MoE, Kingdom of Saudi Arabia 2007), and affirming commitments and allocating resources through their Ministry of Economic and Planning for the wider integration ICT in education at a national level through the 10th National Development Plan (2015-2019) and National Transformation Program (2016-2020). The Irish Department of Education and Skills (2015b) further sought to enable a triple agenda of economic growth, educational reform and social development through its implementation of the "Digital Strategy for Schools" (2015-2020) and associated innovative operational components, such as the Digital Learning Framework, that aimed to fundamentally change the manner in which ICT was integrated at school level to ensure that learners developed not only key ICT skills but also broader competencies (including: communication skills, interpersonal skills, creativity) that contributed to their personal and social development through more holistic approaches to ICT integration in the learning environment.

The monitoring and assessment of progress vis-à-vis ICT integration in education was articulated within the framing of the policies, strategies and programmes in the Kingdom of Saudi Arabia and the Republic of Ireland, however, very few evaluation reports were available from governmental sources in either country. In the Kingdom of Saudi Arabia, the monitoring of the effectiveness or otherwise of plans and programmes was anecdotally reported to have been undertaken for all programmes, and indeed the review of the General Project for Curriculum Development (1998current) undertaken by the Ministry of Education (2012) constituted evidence of one such evaluation. However, information from the evaluation at Saudi governmental levels of the other strategies and programmes were not located, perhaps because they were not publicly available beyond the relevant Saudi Ministry with responsibility for the relevant programme. Interestingly, Albugami and Ahmed (2015b, online) claimed that in the case of the National Strategy for the Development of Education - King Abdullah Project for General Education Development, or Tatweer project, (MoE, Kingdom of Saudi Arabia 2007) that there was no evidence of evaluation of ICT enabled learning at the time of their literature review which was undertaken 8 years after the implementation of the Tatweer project for integrating ICT in Saudi schools. 
However, some insights on the success or otherwise of the Saudi ICT in education initiatives over the past two decades were found within academic literature. In their small-scale study of ICT implementation in Saudi secondary schools, Albugami and Ahmed (2015a) highlighted the weak communications and monitoring processes as central issues in the translation of Saudi ICT in education policy into practice, noting that 'although there is a Saudi ICT educational policy, it is not well communicated, implemented and re-enforced. Its application is also weak at classroom level' (p.47). In their literature review of ICT implementation in Saudi schools, Albugami and Ahmed (2015b, online) further highlighted several other factors that were hindering ICT in education implementation, including 'inadequate management and organizational support, inadequate training, negative teachers' attitudes towards educational technology, cultural factors, and insufficient infrastructure'. Busays Alghamdi (2018) and Alghamdi (2019) doctoral research studies both offered insights into the integration of technology in an albeit very small number of Saudi primary and post-primary schools that participated in the Tatweer project (2007-2023). According to Busays Alghamdi following the review of the General Project for Curriculum Development (1998) by the Ministry of Education in 2012, the MoE did relinquish some control in what has been framed as the second phase of the Tatweer project, by allowing schools some autonomy in relation to identifying their own needs with respect to ICT in integration and governmental support being provided to address the individual needs of these schools. However, Busays Alghamdi (2018) asserted that progress enabled through this school-based model was stifled by lack of stakeholder participation throughout the curriculum design process. In this regard, Busays Alghamdi (2018) claimed there was a need for enhanced stakeholder engagement (teachers, school heads, students and policy-makers) across the process of planning, designing and implementing curriculum re-orientation for successful ICT integration in education. While generalisations cannot be made from these studies, Busays Alghamdi (2018) and Alghamdi (2019) also pointed to issues in the meaningful integration of ICT in the reviewed Tatweer schools, and asserted that there was a need for more teacher professional development in ICT integration in education and ICT skills, and to upgrade equipment and provide technical support.

The detailing of evaluation strategies, in the form of performance indicators, within certain Irish policies and programmes was extensive and sought at its core to be able to measure progress with respect to the integration ICT in education. However, similar to the KSA context, there was a paucity of information from these evaluations available for review from governmental levels on the Action Plan for Education (2016-2019), ICT Skills Action Plan (2014-2018), Digital Strategy for Schools (2015-2020) and the Framework for Junior Cycle (2015), with reliance on limited academic literature and other sources to gain some insights into how these were being evaluated and their impact on ICT integration at primary and post-primary schools. For example, Cosgrove et al. (2019) evaluation of the Digital Learning Framework, one aspect of the Digital Strategy for Schools (2015-2020), was useful with respect to enabling better understanding the impact of this operational component of integration ICT in schools. However, in the absence of publicly available information, it was necessary to review the follow-up strategy to the ICT Skills Action Plan (2014-2018) to glean information on its performance. In this regard, within the "Technology Skills 2022: Ireland's Third ICT Skills Action Plan” the DES (2019) acknowledged the success of its predecessor in 
enabling increased uptake of third level ICT-related courses but provided minimal information on the effectiveness of ICT integration at school level, referring instead to the uptake of post-primary students of ICT summer and autumn camps, and the inclusion of coding and computer science as courses at post-primary levels. Interestingly, the DES planned that the Framework for Junior Cycle (2015) was to be evaluated at the level of the school, within school self-evaluation (SSE) and improvement exercises, and this process monitored by the DES and its Inspectorate. The challenge herein was that SSE reports were brief documents, with no requirement from schools to specifically reflect on ICT integration in learning, and this individual reporting by schools made the task of reviewing the overall effectiveness of the framework from a national perspective undoable within the timeframe of this review process.

In terms of operational components, the comparative review of policies and programmes showed that infrastructure development, teacher training in ICT, content development and needs for pedagogical support were articulated within action plans, projects and/ or programmes focused on ICT integration across both jurisdictions. In his review of the literature on barriers to ICT usage in teaching in Saudi Arabia, Al Mulhim (2014) cited issues of lack of effective training and lack of time as impacting on ICT integration in practice by Saudi teachers. Albugami and Ahmed (2015a) noted that while there was interest in accessing ICT training among Saudi teachers who participated in their study, the training times were not always convenient, and teachers may need to be incentivised to undertake ICT training if outside of working hours. Alenezi (2016, online) pointed to delays in shifting from ICT adoption to ICT implementation as mandated by governmental policies, which he asserted was being caused by teachers' becoming conflicted in transitioning from traditional offline methods of education to new ICT enabled learning environments, and lack of equipment in working order, where he asserted that 'Saudi schools have had problems with making ICT tools available in working condition'. Albugami and Ahmed (2015a) further asserted that the constant breakdowns of computer equipment and the lack of technical assistance to repair equipment impacted on teachers' confidence, and subsequent integration of ICT in their educational practice. Interestingly, the comparative review of policies showed that provision for ICT technical support was made explicit in the Saudi Tatweer project (2007-2023) and within the strategies, action plans and programmes reviewed from the Irish context. However, Al Mulhim's (2014) literature review of the implementation of ICT in Saudi schools pointed to an ongoing issue of technical support, as well as issues with access to technology and the high cost of hardware and software, as an obstacle to ICT integration in education. Furthermore, Alkahtani's (2017) study of the challenges in integrating ICT in education across four Saudi post-primary schools that participated in the Tatweer project (2007-2023), highlighted the challenge of teachers lacking working equipment and inadequate equipment maintenance, and further pointed to an issue in the long-term financial resourcing for ICT in education programmes "The refusal of the [Tatweer] Project to continue paying for technical support, maintenance and repair of equipment was striking, because this was a necessary and critical component" (p.41). Similarly, the issue of resourcing for technical support exists within the Irish context, and has arguably prevailed since the "Schools IT 2000" policy (DES, Republic of Ireland 1997), during which time 
the "School ICT coordinators, introduced for the first time in 1999, also felt exploited, since they had to carry out all the technical work, as no funding was available for technicians" (Austin and Hunter 2013, p.188). Cosgrove et al. (2019) also noted in their evaluation of the Digital Learning Framework, the ongoing issue of inadequate provision or implementation of technical support (particularly on-site technical support) and further suggested that schools might form clusters to make the allocation of technical support financially workable within the Irish context.

\section{Limitations of the study}

According to Geva-May et al. (2018, p.23) comparative reviews can provide valuable insights into how programmes operate but also have limitations in terms of the transferability of findings within a different jurisdiction as "...the fact that they are foreign introduces an element of speculation whether they can transfer". The intention here was not to benchmark the progress in the Kingdom of Saudi Arabia against that in the Republic of Ireland, but rather to consider each national context independently and draw 'learnings' where possible rather than 'lessons' as asserted by Rose (1991), for either jurisdiction. Therefore, the notion of enabling transferability of findings from either context was discounted in favour of revealing 'possibilities' for the re-orientation of policies, strategies and programmes seeking to promote the integration of ICT in primary/ postprimary education settings.

In addition, it could further be argued that the absence of stakeholders' perspectives on the enactment of these policies, strategies and programmes within the two countries was a limitation of this study. However, it simply wasn't possible to include stakeholder voices as the protocols and procedures in relation to accessing stakeholders in governmental and school settings in one of the jurisdictions, namely the Kingdom of Saudi Arabia, were multi-layered and complex in terms of seeking approvals and gaining consent, and thus were too protracted to bring to completion within the timeframe of the study. The study nevertheless provides a thorough critique of the framings of policies and programmes across both jurisdictions through the use of Kozma's (2008) framework for comparative analysis of ICT policy in education, and from the integration of perspectives gleaned from limited academic literature reporting on ICT policy implementation in these national contexts.

\section{Conclusion}

This comparative review has shown that the policies, strategies and programmes for integrating ICT in primary and post-primary settings in the Kingdom of Saudi Arabia and the Republic of Ireland have overlapping underpinning rationales in terms of economic growth and educational reform, as well as social development (although to a lesser extent in KSA). The framing of these policies, strategies and programmes have involved consultations (and in some cases partnerships) with a wide range of stakeholders at governmental levels, school level, industry and 
connected communities, but would benefit from extending the consultation and indeed strengthening partnerships throughout the life-cycle of ICT integration in education, thus, involving all stakeholders at the levels of planning, implementation and evaluation of policies, strategies and programmes to enhance ICT integration in primary and post-primary settings. The possibilities for improvements in both jurisdictions include providing adequate financial and human resourcing to fully operationalize the teacher training and supports necessary for effective integration by teachers of ICT in primary and post-primary settings. Furthermore, the evaluation strategies and performance indicators in both countries need to be re-visited to ensure that evidence of their enactment is publicly available, and so that the resultant evaluation reports are detailed at a level that make visible the national progress with respect to the meaningful integration of technology in schools, and the corresponding impact on not only learners' ICT skills but the broader suite of learner competencies contributing to their personal and social development.

Availability of data and material The material used in this comparative review of ICT in education policies, strategies and programmes is openly available for others to review.

Authors' contribution This is a co-authored paper, with equal contribution from the joint authors

Funding information This research study was funded by Imam Abdulrahman Bin Faisal University in the form of a doctoral research scholarship granted to the lead co-author.

\section{Compliance with ethical standards}

Conflicts of interest/ competing interests Not applicable.

Open Access This article is licensed under a Creative Commons Attribution 4.0 International License, which permits use, sharing, adaptation, distribution and reproduction in any medium or format, as long as you give appropriate credit to the original author(s) and the source, provide a link to the Creative Commons licence, and indicate if changes were made. The images or other third party material in this article are included in the article's Creative Commons licence, unless indicated otherwise in a credit line to the material. If material is not included in the article's Creative Commons licence and your intended use is not permitted by statutory regulation or exceeds the permitted use, you will need to obtain permission directly from the copyright holder. To view a copy of this licence, visit http://creativecommons.org/licenses/by/4.0/.

\section{References}

Albugami, S., \& Ahmed, V. (2015a). Success factors for ICT implementation in Saudi secondary schools: From the perspective of ICT directors, head teachers, teachers and students. International Journal of Education and Development using Information and Communication Technology (IJEDICT), 11(1), 3654.

Albugami, S. and Ahmed, V. (2015b). Towards successful implementation of ICT in Saudi schools (literature review), http://usir.salford.ac.uk/37662/. Accessed 28 January 2020.

Alkahtani, A. (2017). The challenges facing the integration of ICT in teaching in Saudi secondary schools. International Journal of Education and Development using Information and Communication Technology (IJEDICT), 13(1), 32-51. 
Al Mulhim, E. (2014). The barriers to the use of ICT in teaching in Saudi Arabia: A review of literature. Universal Journal of Educational Research, 2(6), 487-493.

Alenezi, A. (2016). Technology leadership in Saudi schools. Journal of Education and Information Technologies, 22, 1121-1132. https://doi.org/10.1007/s10639-016-9477-x.

Alghamdi, J. (2019). A mixed methods study exploring the practice of mathematics education, with a focus on the integration of online gamified mathematics practice activities in primary classroom settings in Saudi Arabia. Unpublished thesis. Dublin City University: Dublin, Ireland.

Austin, R., \& Hunter, W. (2013). ICT policy and implementation in education: Cases in Canada, Northern Ireland and Ireland. European Journal of Education, 48(1), 178-192.

Busays Alghamdi, S. O. (2018) Curriculum innovation in selected Saudi Arabia public secondary schools: The multi-stakeholder experience of the Tatweer project. Unpublished thesis, University of Leeds, United Kingdom. http://etheses.whiterose.ac.uk/23683/1/AutoRecovery $\% 20$ save $\% 20$ of $\% 20$ Revised $\% 20$ thesis\%5B24312\%5D.asd.pdf. Accessed 26 January 2020.

Butler, D., Hallissy, M. \& Hurley, J. (2018). The digital learning framework: What digital learning can look like in practice, an Irish perspective. In E. Langran \& J. Borup (Eds.), Proceedings of Society for Information Technology \& Teacher Education International Conference (pp. 1339-1346). Washington, DC: Association for the Advancement of computing in education (AACE). https://www.learntechlib. org/p/182702. Accessed 2 February 2020.

Conway, P., \& Brennan Freeman, E. (2009). National policies and practices on ICT in education: Ireland. In T. Plomp, N. Law, \& J. Pelgrum (Eds.), Cross-national information and communication technology. Policies and practices in education (pp. 383-402). Charlotte: Information age publishing.

Conway, P.F. \& Brennan Freeman, E. (2015). The evolution of ICT policy in Ireland 1995-2012: Progress, missed opportunities and future trends. In: Shaping the Future: How Technology Can Lead to Educational Transformation. Dublin: Liffey Press.

Cosgrove, J., Moran, E., Feerick, E., \& Duggan, A. (2019). Digital learning framework (DLF) national evaluation: Starting off. Baseline report. Dublin: Educational Research Centre, http://www.erc.ie/wpcontent/uploads/2020/01/DLF-national-evaluation-baseline-report.pdf. Accessed 25 January 2020.

Department of Education and Science, DES, Republic of Ireland. (1997). Schools IT 2000: A policy framework for the new millennium. Dublin: Stationery Office.

Department of Education and Science, DES, Republic of Ireland. (2001). Blueprint for the Future of ICT in Irish Education, https:/www.pdsttechnologyineducation.ie/en/PUBLICATIONS/Other-PublicationsReports/Blueprint-for-the-Future-of-ICT-in-Irish-Education.PDF. Accessed 21 June 2015.

Department of Education and Science, DES, Republic of Ireland. (2005). An evaluation of curriculum implementation in primary schools: English, mathematics and visual arts. Dublin: Stationery Office.

Department of Education and Science, DES, Republic of Ireland (2008a). ICT in schools. Inspectorate Evaluation Studies, http:/www.education.ie/en/Publications/Inspection-Reports-Publications/EvaluationReports-Guidelines/ICT-in-Schools-Inspectorate-Evaluation-Studies.pdf. Accessed 20 June 2015.

Department of Education and Science, DES, Republic of Ireland. (2008b). Investing Effectively in Information and Communications Technology in Schools (2008-2013), https://www.education. ie/en/Publications/Policy-Reports/Investing-Effectively-in-Information-and-Communication-Technologyin-Schools-2008-2013.pdf. Accessed 24 January 2020.

Department of Education and Science, Republic of Ireland. (2009). Smart Schools = Smart Economy, https://www.into.ie/ROI/Publications/OtherPublications/OtherPublicationsDownloads/Sma rtSchools= SmartEconomy.pdf. Accessed 20 January 2015.

Department of Education and Skills (DES) \& Department of Jobs, Enterprise \& Innovation (DJEI), Republic of Ireland. (2014). ICT Skills Action Plan 2014-2018,https:/www.education.ie/en/Publications/PolicyReports/ICT-Skills-Action-Plan-2014-2018.pdf. Accessed 16 May 2017.

Department of Education and Science, Republic of Ireland. (2015a). Framework for junior certificate 2015. Stationary Office: Dublin https://www.education.ie/en/Publications/Policy-Reports/Framework-forJunior-Cycle-2015.pdf. Accessed 18 May 2017.

Department of Education and Science, Republic of Ireland. (2015b). Digital Strategy for School, 2015-2020. https://www.education.ie/en/Publications/Policy-Reports/Digital-Strategy-for-Schools-2015-2020.pdf. Accessed 9 May 2017.

Department of Education and Science, Republic of Ireland. (2016). Action Plan for Education 2016-2019. https://www.education.ie/en/The-Department/Public-Service-Reform/Education-and-Training-SectorIntegrated-Reform-Delivery-Plan-Revised-2016.pdf. Aaccessed 13 May 2017.

Geva-May, I., Hoffman, D. C., \& Muhleisen, J. (2018). Twenty years of comparative policy analysis: A survey of the field and a discussion of topics and methods. Journal of Comparative Policy Analysis: Research and Practice, 20(1), 18-35. 
Government of Ireland, GOI. (2007). Ireland National Development Plan 2007-2013. Transforming Ireland: A better quality of life for all. Dublin, Ireland: Stationary Office.

Kingdom of Saudi Arabia. (2016a). Saudi Vision 2030. https://vision2030.gov.sa/en. Accessed 16 June 2017.

Kingdom of Saudi Arabia. (2016b). National Transformation Programme (NTP) 2020. https://vision2030.gov. sa/sites/default/files/NTP En.pdf. Accessed 16 June 2017.

Kozma, R. (2008). ICT, Education Reform, and Economic Growth: A Conceptual Framework. http://download.intel.com/education/EvidenceOfImpact/Kozma_ICT_Framework.pdf . Accessed 12 June 2017.

Higher Education Authority (2017) Higher Education Factsheet: Internationalisation: Locally Educated, Globally Connected. http://eurireland.ie/assets/uploads/2018/02/INT-Factsheet-Final-PDF-version.pdf . Accessed: $22^{\text {nd }}$ January 2020.

Johnston, K. T. (2014). The development and implementation of ICT policy for schools in the Irish postprimary context: A critical analysis. Unpublished Thesis. University of Limerick, Ireland.https://ulir.ul. ie/bitstream/handle/10344/4006/Johnston_2014_development.pdf?sequence=5. Accessed 25 January 2020.

Kozma, R. (2008). ICT, Education Reform, and Economic Growth: A Conceptual Framework. http://download.intel.com/education/EvidenceOfImpact/Kozma_ICT_Framework.pdf. Accessed 12 June 2017.

Marcus-Quinn, A. \& McGarr, O. (2013). Digital divide in post-primary schools. IN Internet Research, Theory, and Practice: Perspectives from Ireland. Eds: Fowler, C., English, C., \& Thouësny, S. pp.277-304. Research-publishing.net: Dublin, Ireland; Voillans, France.

McGarr, O. (2009). The development of ICT across the curriculum in Irish schools: A historical perspective. British Journal of Educational Technology, 40(6), 1094-1108.

Ministry of Planning, MoP, Kingdom of Saudi Arabia. (1990). The 5th National Development Plan (19901995). https://www.mep.gov.sa/en/development-plans. Accessed 12 January 2015.

Ministry of Planning, MoP, Kingdom of Saudi Arabia. (1996). The 6th National Development Plan (19962000). https://www.mep.gov.sa/en/development-plans. Accessed 12 January 2015.

Ministry of Planning, MoP, Kingdom of Saudi Arabia. (2000). The 7th National Development Plan (20002004). https://www.mep.gov.sa/en/development-plans. Accesse: 12 January 2015.

Ministry of Economy and Planning, MoEP, Kingdom of Saudi Arabia. (2005). The 8th National Development Plan (2005-2009). https://www.mep.gov.sa/en/development-plans. Accessed 12 Jan 2015.

Ministry of Economy and Planning, MoEP, Kingdom of Saudi Arabia. (2010). The 9th National Development Plan (2010-2014). https://www.mep.gov.sa/en/development-plans. Accessed 12 Jan 2015.

Ministry of Economy and Planning, MoEP, Kingdom of Saudi Arabia. (2015). The 10th National Development Plan (2015-2019). http://www.nationalplanningcycles.org/sites/default/files/planning _ cycle_repository/saudi_arabia/10th-development-plan-.pdf. Accessed 12 March 2018.

Ministry of Education, MoE, Kingdom of Saudi Arabia. (1998). The General Project for Curriculum Development.http://www.almarefh.net/show_content_sub.php?CUV=393\&Model=\&SubModel=138 $\& \mathrm{ID}=1402 \&$ ShowAll=On. Accessed 20 May 2015.

Ministry of Education, MoE, Kingdom of Saudi Arabia. (2000). Abdullah bin Abdul Aziz and his Student sons Project for Computer (Watani). http://www.al-jazirah.com/2001/20011016/ln61.htm. Accessed 20 Jan 2015.

Ministry of Education, MoE: Tatweer Education Holding Company, TEHC, Kingdom of Saudi Arabia. (2007). The National Strategy for the Development of Education, King Abdullah Project for General Education Development Tatweer Project: 2007-2023. https://www.tatweer.edu.sa/Storage/strategy.pdf. Accessed 16 May 2017.

Ministry of Education, MoE, Kingdom of Saudi Arabia. (2012). The development of general education in the Kingdom of Saudi Arabia; Achievements, Aspirations and Challenges. http://docplayer.net/61813718Ttwyr-lt\%60lym-1\%60m-fy-lmmlk@-njzt-wttl\%60t-wthdyt.html. Accessed 12 February 2018.

Rose, R. (1991). What is lesson-drawing? Journal of Public Policy, 11(1), 3-30.

Publisher's note Springer Nature remains neutral with regard to jurisdictional claims in published maps and institutional affiliations. 


\section{Affiliations}

\section{Jawaher Alghamdi ${ }^{1} \cdot$ Charlotte Holland $^{2}$}

Charlotte Holland

charlotte.holland@dcu.ie

1 Department of Curriculum and Teaching methods, College of Science and Humanities, Imam Abdulrahman Bin Faisal University, Jubail, Saudi Arabia

2 School of STEM Education, Innovation and Global Studies, DCU Institute of Education, Dublin City University, Dublin, Ireland 